\title{
Prognostic Significance of Immunohistochemical P53 Expression in Patients with Breast Cancer
}

\section{Meme Kanseri Tanılı Hastalarda İmmunhistokimyasal Olarak P53 Ekspresyonunun Prognostik Önemi}

\author{
Betül Bolat Küçükzeybek, Halil Taşkaynatan, Seyran Yiğit, Yaşar Yıldız, Ayşegül Akder Sarı, Utku \\ Oflazoğlu, Demet Etit, Ayşe Yazıcı, Kemal Atahan, Ahmet Alacacıoğlu, Umut Varol, Yüksel Küçükzeybek \\ ${ }^{1}$ İzmir Katip Çelebi Üniversitesi Atatürk Eğitim ve Araştırma Hastanesi, Tıbbi Patoloji Kliniği, İzmir \\ ${ }^{2}$ İzmir Katip Çelebi Üniversitesi Atatürk Eğitim ve Araştırma Hastanesi, Tıbbi Onkoloji Kliniği, İzmir \\ ${ }^{3}$ İzmir Katip Çelebi Üniversitesi Atatürk Eğitim ve Araştırma Hastanesi, Genel Cerrahi Kliniği, İzmir
}

\section{ÖZET}

GİRIŞ ve AMAÇ: Meme kanseri kadınlarda en sık görülen ve ölüme neden olan kanserler arasında ikinci sırada yer almaktadır. p53 hücre siklusunda santral rol oynayan önemli bir tümör supresördür ve meme kanserinde yaklaşık \%20-30 oranında TP53 gen mutasyonu saptanmaktadır. TP53 gen mutasyonu ve immunhistokimyasal p53 ekspresyonu korelasyonu gösterilmiştir. Bu çalışmada meme kanseri hastalarında immunhistokimyasal p53 ekspresyonunun prognostik öneminin değerlendirilmesi amaçlanmıştır.

YÖNTEM ve GEREÇLER: Bu çalışmaya 2006-2012 yılları araşında İzmir Katip Çelebi Üniversitesi Atatürk Eğitim ve Araştırma Hastanesi Patoloji Bölümünde tanısı konulan ve Tıbbi Onkoloji kliniğinde izlemi bulunan opere meme kanserli hastalar dahil edildi. İmmunhistokimyasal olarak nükleer p53 ekspresyonunun patolojik ve klinik prognostik göstergelerle ilişkisi değerlendirildi.

BULGULAR: Çalışmaya 395 meme kanseri tanılı hasta dahil edildi. İkiyüzüç $(\% 51,4)$ hastada p53 ekspresyonu saptand1. Moleküler alttiplere göre p53 boyanma yüzdeleri değerlendirildiğinde p53 ekspresyonu en düşük oranda luminal A ve Luminal B-Her2 negatif grupta saptand. Luminal A ve Luminal B-Her2 negatif grupta saptanan p53 boyanma yüzdeleri diğer alttipler ile karşılaştırıldığında istatistiki anlamlı farklılık olduğu saptanmıştır $(\mathrm{p}<0,05)$. p53 ekspresyonuna göre hastalar iki gruba ayrıldığında, iki grup arasında sağkalımlar açısından fark saptanmadı ( $>00,05)$. p53 ekspresyonu ile histolojik grad ve Ki-67 proliferasyonu arasında pozitif korelasyon, östrojen reseptör ekspresyonu ile negatif korelasyon saptand $1(\mathrm{p}<0,05)$.

TARTIŞMA ve SONUÇ: Çalışmamızda p53 ekspresyonunun kötü prognoz ile ilişkili olabileceği gösterilmiştir. Mutant P53 proteinini hedefleyen tedaviler ile ilgili preklinik ve klinik çalışmaların artması, immunhistokimyasal olarak p53 ekspresyonunun prognostik ve prediktif önemini ortaya çıkaracaktır.

Anahtar Kelimeler: Meme kanseri, p53 mutasyonu, prognoz

\begin{abstract}
INTRODUCTION: Breast cancer is the second most common cancer in women and the second leading cause of cancer death. p53 is an important tumor suppressor that plays a central role in cell cycle and TP53 gene mutations are detected in about $20-30 \%$ of patients with breast cancer. The correlation between TP53 gene mutation and immunohistochemical p53 expression has been demonstrated. The present study aims to evaluate the prognostic significance of immunohistochemical p53 expression in breast cancer patients.

METHODS: The present study evaluated patients with breast cancer who were diagnosed at Izmir Katip Celebi University, Ataturk Training and Research Hospital, Department of Pathology from 2006 to 2012, and who were followed up at the Medical Oncology clinic. Immunohistochemical nuclear p53 expression was assessed in relation to pathological and clinical prognostic factors.
\end{abstract}

RESULTS: This study included 395 patients with breast cancer. p53 expression was detected in 203 (51.4\%) patients. The p53 staining values were compared according to molecular subtypes; p53 expression was the lowest in luminal A and Luminal B-Her2 negative groups. The p53 staining percentages in luminal A and luminal B-Her2 negative groups were found to be statistically significantly different when compared to other subtypes $(\mathrm{p}<0.05)$. Patients were divided into two groups according to p53 expression and no difference in survivals was found between the two groups. p53 expression was positively correlated with both Ki-67 
proliferation index and histological grade, and there was a negative correlation between p53 expression and estrogen receptor expression $(\mathrm{p}<0.05)$.

DISCUSSION and CONCLUSION: In this study, it has been shown that p53 expression may be associated with poor prognosis. The increased preclinical and clinical studies on treatments targeting mutant p53 protein will reveal the prognostic and predictive importance of immunohistochemical p53 expression.

Keywords: Breast cancer, p53 mutation, prognosis

\section{GíRiș}

Meme kanseri kadınlarda en sık görülen ve ölüme neden olan kanserler arasinda ikinci sirada yer alan kanserdir (1). Meme kanseri heterojen bir hastalik grubudur. 2000'li y1llardan sonra meme kanseri gen ekspresyon profiline göre de sınıflanmaya başlanmıştır. Başlıca Luminal A, Luminal B, Her2 pozitif, bazal benzeri olmak üzere 4 alttipe ayrılmıştır. Alttipler arasında klinik davranış, sağkalımlar ve tedaviye yanıt açısından da farklılık mevcuttur (2).

P53 hücre siklusunda santral rol oynayan önemli bir tümör supresördür, transkripsiyon faktörü olarak görev alır. DNA hasar1, hipoksi, oksidatif stres, onkogen aktivasyonu, telomer erezyonu gibi hücresel stres sinyalleri sonrasinda p53 aktive olur. Hücre siklusu arresti, DNA tamiri ve eğer meydana gelen hasar tamir edilemeyecekse apopitozisde rol oynayan p53 hedef genlerinin ekspresyonu ile sonuçlanır. P53 hedef genleri ayrıca hücresel yaşlanma, anjiogenez ve otofajide de rol oynar $(3,4)$. Hücresel p53 protein düzeyleri, p53'ün negatif regülatörleri olan MDMX ve MDM2 tarafindan s1k1 kontrol altındadır (5). P53 güçlü bir tümör supresördür. Kanserlerin \%50'den fazlasinda P53 proteini TP53 gen mutasyonu nedeniyle inaktive durumdadır. TP53 gen mutasyonunun prevelansı çeşitli kanserlerde farklıdır. En yüksek oranda küçük hücreli akciğer kanserinde (\%80) ve over kanserinde (\%90) saptanmaktadır (6). Küçük hücreli dışı akciğer kanseri histolojik alttipleri arasinda farklılık gösterilmiştir (7). Meme kanseri alttipleri arasında da TP53 gen mutasyonu bakımından farklı1ık saptandığı gösterilmiştir. Luminal A tipte düşük oranda, Her2 pozitif ve bazal benzeri alttiplerde ise yüksek oranda saptanmaktadır $(2,8)$.

$\mathrm{Bu}$ çalışmada opere meme kanseri tanilı hastalarda immunohistokimyasal (IHK) olarak değerlendirilen p53 ekspresyonunun prognostik öneminin retrospektif olarak değerlendirilmesi planlanmıştır.

\section{GEREÇ ve YÖNTEM}

Hastalar ve doku örnekleri: 2006-2012 yıllar1 arasında İzmir Katip Çelebi Üniversitesi Atatürk Eğitim ve Araştırma Hastanesi Tibbi Patoloji Laboratuvarında tanı konulan ve Tibbi Onkoloji Kliniğinde izlemi bulunan opere meme kanseri tanılı hastalar çalışmaya dahil edilmiştir. Hastaların demografik verileri ve sağkalım verileri tıbbi onkoloji polikliniğindeki izlem dosyalarından temin edildi. TNM ye göre evreleme yapıldı (9). Tanı sırasındaki evre, tümör boyutu, hasta yaşı, lenf nodu statusu, lenfovasküler invazyon varlığ 1 , rekürrens veya metastaz gelişimi, adjuvan kemoterapi kullanımı, histolojik gradı içeren klinik ve patolojik veriler hasta dosyalarından temin edildi. Hastalıksız sağkalım (HSK), tanı tarihinden itibaren nüks/metastaz gelişimine kadar ya da son izlem tarihine kadar geçen süre, genel sağkalım (GSK) tanı tarihinden itibaren herhangi bir nedene bağlı ölüme kadar geçen süre olarak kabul edildi. Hastalar luminal A, Luminal B-Her2 negatif, Luminal B-Her2 pozitif, Her2 pozitif, Bazal benzeri olmak üzere 5 alttipe kategorize edildi (10). Hastaların patoloji laboratuvarındaki tümör içeren blokları İHK olarak p53 boyanması için kullanıldı. İHK olarak p53 nükleer boyanma yüzdesi değerlendirildi. P53 yanısıra tan1 anında uygulanan östrojen reseptörü (ER), progesteron reseptörü (PR), HER2 ve Ki67 boyalı lamlar tekrar değerlendirildi.

İmmunohistokimyasal yöntem: İHK boyama, formalinde fikse edilmiş parafine gömülü tümör içeren bloklardan 4 mikronluk kesitler alınarak streptavidin-biotin-peroxidase metodu kullanılarak yapıldı. İHK boyama için DAKO otomatik boyama cihazı (DAKO, Santa Clara,CA, ABD) kullanıldı. Kesitler monoclonal mouse anti-human P53 protein (klon DO-7, Dako) ile boyand. İki patoloji uzmanı tarafından İHK değerlendirme yapıldı. Tümör hücrelerinde nükleer boyanma pozitif olarak değerlendirildi ve boyanma yüzdesi belirlendi. Tümör hücrelerinde $\geq \% 1$ nükleer boyanma gösteren olgular pozitif olarak kabul edildi. 


\section{İstatistiksel analiz}

İstatiksel analizler SPSS paket program versiyon 20 kullanılarak yapıldı. Sağkalım analizleri için Kaplan Meier analizi kullanıldı. Hastalar IHHK olarak p53 boyanma varlığı ya da yokluğuna göre iki gruba ayrıldı. İki grup arasındaki sağkalım karşılaştırmaları için log rank test kullanıldı. Sağkalımlar tekli analiz ile karşılaştırıldı. Gruplar arasında boyanma yoğunluğu karşılaştırmaları için independent ttest kullanıldı. P53 pozitifliği açısından gruplar arasında karşılaştırma ki-kare testi ile yapıldı. P53 ekspresyonunun diğer prognostik göstergelerle ilişkisi spearman rho korelasyon testi, Pearson korelasyon testi ile değerlendirildi. $\mathrm{P}$ değeri $\leq 0,05$ istatistiki olarak anlamlı kabul edildi.

\section{BULGULAR}

İzmir Katip Çelebi Üniversitesi Atatürk Eğitim ve Araştırma Hastanesi Tibbi Patoloji Laboratuvarında 2006-2012 y1lları arasında tanı konulan ve Tibbi Onkoloji kliniğinde izlemi bulunan 395 opere meme kanseri tanılı hastada p53 ekspresyonu retrospektif olarak değerlendirildi. Çalışmaya dahil edilen hastaların klinik ve histopatolojik karakteristikleri tablo 1 de gösterilmiştir. Hastaların medyan yaşı 50 (27-82) olarak hesapland. İki yüz üç $(\% 51,4)$ hastada değişik oranlarda p53 ekspresyonu saptanırken, 192 $(\% 48,6)$ hastada p53 ekspresyonu saptanmadı (Resim1 ve Resim2). Çalışmaya dahil edilen hastalar histolojik alt tiplerine göre sinıflandığında, $287 \quad(\% 72,7)$ hasta invaziv duktal karsinom, $29(\% 7,3)$ hasta invaziv lobüler karsinom, $50(\% 12,7)$ hasta mikst tipte karsinom alt tipinde saptandi. Tanı sirasindaki TNM evresine göre $77(\% 19,5)$ hasta evre I, $206(\% 73,2)$ hasta evre II, $112(\% 28,3)$ hasta evre III olarak değerlendirildi. Histolojik grada göre $37(9,4)$ hasta grad 1, $280(70,9)$ hasta grad II, 75 (19) hasta grad III olarak değerlendirildi. Tanı sirasında $149 \quad(37,7)$ hastada lenf nodu negatif, $246(62,3)$ hastada lenf nodu pozitifti. Moleküler alttiplere göre $103(26,1)$ hasta luminal A, $172(43,5)$ hasta luminal B-Her2 negatif, $56(14,2)$ hasta luminal B-Her2 pozitif, $29(7,3)$ hasta Her2 pozitif, $35(8,9)$ hasta bazal benzeri olarak sinifland1. Ki67 proliferasyon indeksi 213(53,9) hastada \%14'ün altında, $62(15,7)$ hastada \%14-30 arasında, 92(23,3) hastada \%30'un üzerinde saptand. Moleküler alttipler arasinda p53 ekspresyonu Luminal A'da 51 $(\% 49,5)$, Luminal B-Her2 negatifte 82 (\%47,7), Luminal B-Her2 pozitifte $36(\% 64,3)$, Her2 pozitif grupta $17(\% 58,6)$, bazal benzeri grupta $17(\% 48,6)$ hastada pozitif saptand1 (Tablo 2). İHK olarak p53 pozitif boyanma oranları açısından moleküler alttipler karşılaştırıldığında, yalnızca Luminal B-HER2 negatif ve Luminal B-Her2 pozitif alttip arasında istatistiki anlamlı farklılık olduğu saptanmıştır $(p<0,031)$. Diğer alttipler arasında IHHK p53 pozitiflik oranı açısından istatistiki anlamlı fark olmadığı saptanmıştır $(p>0,05)$. Ortalama p53 boyanma yüzdeleri Luminal A alttipte \%11,1 Luminal B-Her2 negatif alttipte $\% 18,3$ Luminal B-Her2 pozitif alttipte \%31,3, Her2 pozitif alttipte \%30,9, bazal benzeri alttipte \%28,1 saptanmıştır. Moleküler alttipler arasinda p53 boyanma yüzdeleri değerlendirildiğinde ortalama p53 ekspresyon yüzdesi en düşük oranda luminal A ve Luminal B-Her2 negatif grupta saptanmıştır. Luminal A ve Luminal B-Her2 negatif grupta saptanan p53 boyanma yüzdeleri diğer alttipler ile karşılaştırıldığında istatistiki anlamlı farklılık olduğu saptanmıştır $(\mathrm{p}<0,05)$.

Medyan 84 ayl1k izlemde $77(19,5 \%)$ hastada nüks/metastaz geliştiği saptandı. İzlemde elli $(\% 12,7)$ hasta kaybedildi. Çalışmaya dahil edilen hastaların 8 yıllık HSK oranlar1, Luminal A, Luminal B-Her2 negatif, Luminal B-Her2 pozitif, bazal benzeri ve Her2 pozitif grupta sirasiyla \%92,1, \%78,6, \%77,7, $\% 64,9, \% 52,1$ saptanmıştır. Sekiz yıllık HSK oranlar1 p53 mutasyonu saptanan ve saptanmayan grupta, $\% 74,3$ ve $\% 82,4$ saptanmıştır. İki grup arasındaki fark istatistiki olarak anlamlı bulunmamıştır $(\mathrm{p}=0,22)$ (resim 3). p53 ekspresyonu \%10'dan fazla ve $\% 10$ 'dan düşük olan grupların 8 yıllık HSK oranları \% $\% 2.3$ ve \%81.8 saptanmıştır. İki grup arasındaki fark istatistiki olarak anlamlı bulunmamıştır $(p=0.107)$. Çalışmaya dahil edilen hasta alttipleri arasinda en uzun GSK 8 yıllık \%97,8 ile luminal A grupta saptand. Sekiz yıllık GSK oranları sirasiyla Luminal BHer2 negatif Luminal B-Her2 pozitif, Her2 pozitif, bazal benzeri grupta, \%84,5, \%81,7, $\% 75,2$ ve $\% 73$ olarak hesaplanmıştır. P53 ekspresyonuna göre 8 yıllık GSK oranları p53 ekspresyonu saptanan grupta \%87,1, p53 ekspresyonu saptanmayan grupta ise \% 86,1 
saptanmıştır. İki grup arasında GSK açısından istatistiki anlamlı fark saptanmamıştır (p0,93) (Resim 4). P53 ekspresyonu \%10'dan fazla olan hasta örnekleri pozitif boyanma olarak kabul edildiğinde, p53 ekspresyonu \%10'dan fazla olan ve \%10'dan düşük olan grubun 8 y1llı GSK oranları \%83.6 ve \%88.6 saptanmıştır. İki grup arasındaki fark istatistiki olarak anlamlı bulunmamıştır $\quad(p=0.143)$. Moleküler alt tiplerde p53 ekspresyonuna göre GSK oranları değerlendirildiğinde p53 ekspresyonu saptanan ve p53 ekspresyonu saptanmayan hastalar arasinda GSK fark1 saptanmamıştır $\quad(\mathrm{p}>0,05) . \quad$ Korelasyon analizinde p53 ekspresyonunun histolojik grad $(\mathrm{p}<0,001)$ ve Ki67 proliferasyon indeksi $(\mathrm{p}<0,001)$ ile pozitif korelasyon gösterdiği, östrojen reseptör ekspresyonu $(\mathrm{p}<0,001)$ ile negatif korelasyon gösterdiği saptanmıştır.

Tablo 1. Hasta Karakteristikleri

\begin{tabular}{|l|c|}
\hline & $\mathrm{N}=395(\%)$ \\
\hline Hasta Karakteristikleri & $50(27-82)$ \\
\hline p53 Ekspresyonu & \\
Pozitif & $203(51,4)$ \\
Negatif & $192(48,6)$ \\
\hline Tan1 sirasindaki evre & \\
I & $77(19,5)$ \\
II & $206(73,2)$ \\
III & $112(28,3)$ \\
\hline Moleküler alttip & \\
Luminal A & $103(26,1)$ \\
Luminal B-Her2 Negatif & $172(43,5)$ \\
Luminal B-Her2 Pozitif & $56(14,2)$ \\
Her2 Pozitif & $29(7,3)$ \\
Bazal Benzeri & $35(8,9)$ \\
\hline Lenf nodu metastaz1 & \\
Negatif & $149(37,7)$ \\
Pozitif & $246(62,3)$ \\
\hline Histolojik Grad & \\
I & $37(9,4)$ \\
II & $280(70,9)$ \\
III & $75(19)$ \\
\hline Ki-67 Proliferasyon İndeksi & $213(53,9)$ \\
<14 & $62(15,7)$ \\
14-30 & $92(23,3)$ \\
\hline >30 & \\
\hline
\end{tabular}

Tablo 2. Moleküler alt tiplere göre p53 ekspresyonu

\begin{tabular}{|l|l|c|}
\hline Moleküler Tip & $\begin{array}{l}\text { p53 } \\
\text { ekspresyonu }\end{array}$ & $\mathrm{n}(\%)$ \\
\hline \multirow{2}{*}{ Luminal A } & Negatif & $52(50,5)$ \\
\cline { 2 - 3 } & Pozitif & $51(49,5)$ \\
\hline \multirow{2}{*}{ LuminalBher2negatif } & Negatif & $90(52,3)$ \\
\cline { 2 - 3 } & Pozitif & $82(47,7)$ \\
\hline \multirow{2}{*}{ LuminalBher2pozitif } & Negatif & $20(35,7)$ \\
\cline { 2 - 3 } & Pozitif & $36(64,3)$ \\
\hline \multirow{2}{*}{ HER2 } & Negatif & $12(41,4)$ \\
\cline { 2 - 3 } & Pozitif & $17(58,6)$ \\
\hline \multirow{2}{*}{ Bazal-Benzeri } & Negatif & $18(51,4)$ \\
\cline { 2 - 3 } & Pozitif & $17(48,6)$ \\
\hline
\end{tabular}

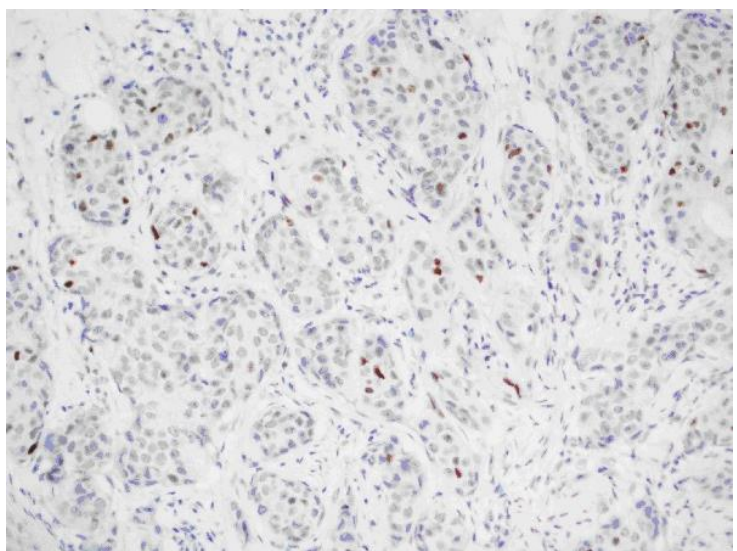

Resim 1. İmmunohistokimyasal olarak tümör hücrelerinde fokal p53 pozitifliği (x20)

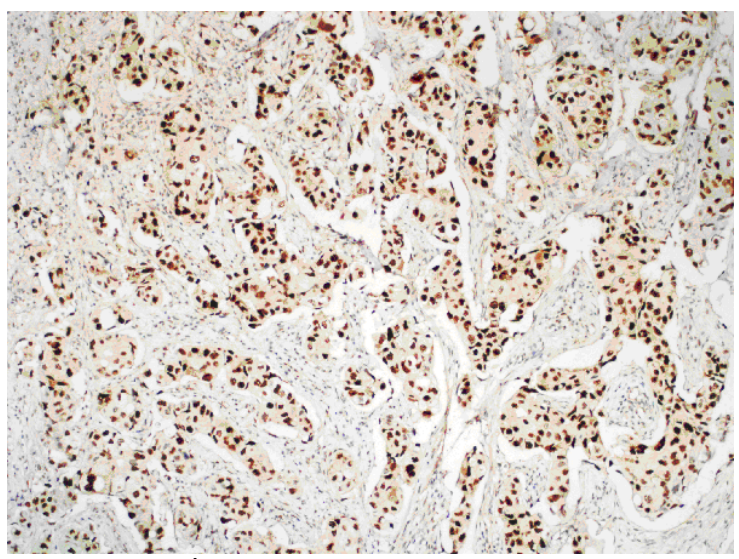

Resim 2. İmmunohistokimyasal olarak tümör hücrelerinde diffüz, güçlü p53 pozitifliği (x10) 


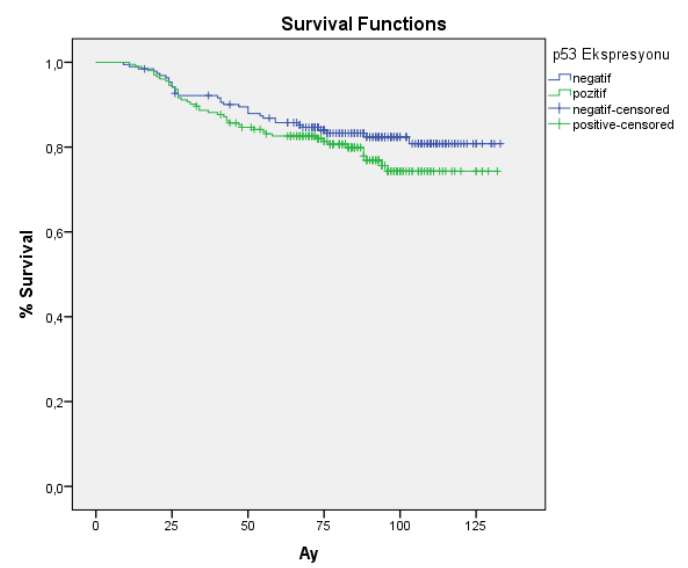

Resim 3. P53 Ekspresyon varlığına göre Hastalıksız Sağkalım Eğrisi (p 0,22)

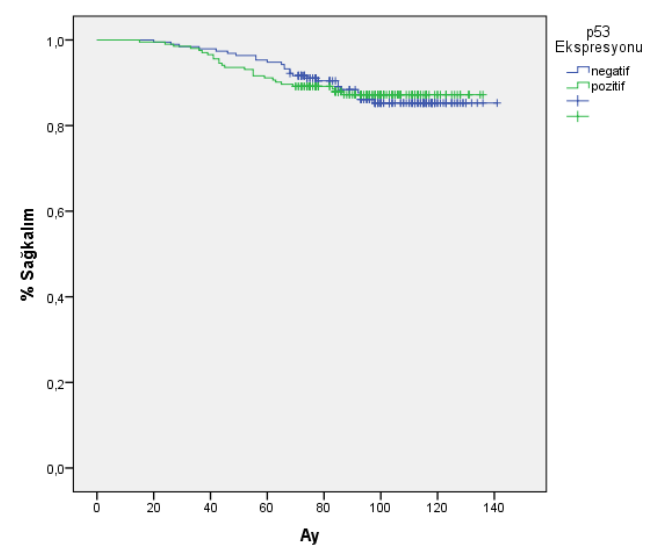

Resim 4. P53 Ekspresyon varlığına göre Genel Sağkalım Eğrisi (p0,93)

\section{TARTIŞMA}

TP53 gen mutasyonları fonksiyon kayb1 ya da fonksiyon kazanımı ile karakterizedir. TP53 gen mutasyonu, mutant p53 protein stabilizasyonu ile sonuçlanmaktadır. Kısa yarı ömürlü yabanıl tip p53 proteini operasyon materyallerinde IHK olarak saptanamamaktadır. Fakat mutant p53 proteini nukleusta birikir ve İHK olarak saptanmaktadır. (11). P53 İHK pozitifliğinin TP53 gen mutasyonu ile büyük oranda uyumlu olduğu gösterilmiştir. Murnyak ve arkadaşlarının yaptıkları çalışmada TP53 gen mutasyonlarının \% $\% 5$ 'den fazlasının İHK olarak saptandığı belirtilmiştir (12). Yapılan çalışmalarda meme kanserinde yaklaşık \%2030 TP53 gen mutasyonu gösterilmiştir. Sorlie ve arkadaşlarının yaptıkları çalışmada TP53 mutasyon oranlar1, Luminal A alttipte \%13, bazal benzeri alttipte $\% 71$, Her2 pozitif alttipte
\%82 oranında saptanmıştır (2). Dumay ve arkadaşlarının çalışmasında Luminal alttipte $\% 26$, bazal benzeri alttipte $\% 88$ oranında TP53 mutasyonu saptanmıştır (8). Silwall-Pandit ve arkadaşlarının yaptıkları çalışmada Luminal A alttipte \%9.3, Luminal B alttipte \%24.8, bazal benzeri alttipte $\% 53.4$, Her2 pozitif alttipte $\% 65$ oranında TP53 gen mutasyonu saptanmıştır (13). İHK olarak TP53 gen mutasyonundan daha yüksek oranda p53 pozitiflikleri saptanabilmektedir. $\mathrm{Bu}$ durum TP53 gen mutasyonundan bağımsız mekanizmalarla da p53 mutasyonunun meydana gelebileceğini düşündürmektedir. $\mathrm{Bu}$ nedenle p53 mutasyonunun prognostik öneminin değerlendirilmesi zorlaşmaktadır. TP53 gen mutasyonu çoğu kanserde olduğu gibi meme kanserinde de saptanmasına rağmen günümüzde meme kanseri tedavi kararında kullanılmamaktadır (14). Çalışmamıza 395 opere meme kanseri tanil hasta dahil edilmiştir. İHK olarak $203(\% 51,4)$ hastada p53 ekspresyonu saptanmıştır. Çalışmamıza dahil edilen meme kanseri tanılı hastalar moleküler alttiplere göre İHK p53 ekspresyonu bakımından değerlendirildiğinde, en yüksek oranlar Luminal B-Her2 pozitif grupta $(\% 64,3)$ ve Her2 pozitif grupta $(\% 58,6)$ saptanmıştır. İHK p53 pozitifliği moleküler alttipler arasında yalnızca Luminal B-Her2 pozitif ve Luminal B-Her2 negatif arasında anlamlı farklı, diğer alttipler arasinda benzer oranlarda saptanmasina rağmen, P53 ekspresyon yüzdeleri bakımından değerlendirildiğinde ise en düşük ortalama p53 ekspresyon oranları Luminal A ve Luminal B-Her2 negatif grupta saptanmıştır. Luminal A ve Luminal B-Her2 negatif grupta saptanan $\mathrm{p} 53$ boyanma yüzdeleri diğer alttipler ile karşılaştırıldığında istatistiki anlamlı farklılık olduğu saptanmıştır $(\mathrm{p}<0,05)$. Sağkalımları daha iyi olan gruplarda p53 ekspresyonunun düşük saptanmas1, P53 ekspresyonunun prognostik önemi olabileceğini düşündürmektedir. Çalışmaya dahil edilen hastalar p53 ekspresyonu varlığına göre iki gruba ayrıldığında, 8 yıllık HSK oranları ekspresyon saptanan ve saptanmayan grupta $\% 74,3$ ve $\% 82,4$ saptanmıştır. Ekspresyon saptanmayan grupta daha uzun HSK saptanmasına rağmen iki grup arasındaki fark istatistiki olarak anlamlı değildi (p0,22). GSK açısından da iki grup arasında fark saptanmamıştır $\quad(\% 87,1$ ve $\% \quad 86,1)$. Çalışmamızda ayrıca p53 ekspresyonunun 
diğer prognostik göstergelerle korelasyonu değerlendirilmiştir. P53 ekspresyonu ve Ki-67 proliferasyon indeksi ve p53 ekspresyonu ve histolojik grad arasında pozitif korelasyon, p53 ekspresyonu ve ER ekspresyonu arasinda negatif korelasyon saptanmıştır. Allred ve arkadaşlarının 700 opere meme kanseri tanılı hastada p53 ekspresyonunu değerlendirdikleri çalışmada İHK olarak \%52 oranında ekspresyon saptanmıştır. P53 ekspresyonu yüksek proliferasyon indeksi, kötü HSK ve kötü GSK ile ilişkili saptanmıştır (15). Gasparini ve arkadaşlarının 531 meme kanseri tanılı hastayı değerlendirdikleri çalışmada p53 ekspresyonu \%37,5 hastada saptanmıştır. Çoklu analizde p53 ekspresyonunun düşük HSK ve düşük GSK ile ilişkili olduğu gösterilmiştir (16). CALGB9344 çalışmasına dahil edilen 1887 hasta örneğinde p53 ekspresyon oran1 \%27 saptanmıştır. P53 ekspresyonu tekli analizde düşük HSK ve düşük GSK ile ilişkili saptanmasına rağmen çoklu analizde HSK ve GSK ile ilişkili bulunmamıştır (17). Reed ve arkadaşlarının 613 meme kanseri tanilı hastay değerlendirdikleri çalışmada İHK olarak p53 ekspresyonu \%29 oranında saptanmıştır. P53 ekspresyonu sağkalımlar ile ilişkili saptanmamıştır (18). Yamamoto ve arkadaşlarının yaptıkları çalışmada meme kanseri tanılı hastalarda p53 ekspresyonu tümör gradı ve Ki-67 proliferasyon indeksi ile pozitif korele saptanmıştır. P53 ekspresyonu rekürrens gelişimi ile ilişkili saptanmıştır (19). Fountzilas ve arkadaşlarının 1766 hastayı değerlendirdikleri çalışmada p53 ekspresyonu \%53,5 hastada saptanmıştır. Yalnızca Her2pozitif hasta grubunda p53 ekspresyonu HSK ile ilişkili saptanmıştır (20). 174 üçlü negatif meme kanseri tanılı hastanın değerlendirildiği çalışmada İHK olarak p53 pozitifliği \%59 hastada saptanmıştır ve sağkalımlar ile ilişkili bulunmamıştır (21). Çalışmamızda saptanan p53 ekspresyon oran1 ile literatür verileri karşılaştırıldığında çalışmamıza benzer sonuçlar olduğu gibi daha düşük p53 ekspresyon oranları da bildirilmiştir.

Çalışmamızda p53 ekspresyonunun proliferasyon indeksi ve histolojik grad ile pozitif korele olduğu, ER ekspresyonu ile negatif korele olduğu gösterilmiştir. Çalışmamızda elde edilen sonuçlar literatür ile uyumlu olmasına rağmen, p53 ekspresyonunun prognostik öneminin olmadığını gösteren çalışmalar da bulunmaktadır. Bu nedenle İHK olarak p53 ekspresyonunun meme kanseri tanılı hastalarda kötü prognostik gösterge olabileceği düşünülmesine rağmen meme kanseri tedavi kararında günümüzde kullanılmamaktadır.

p53 ekspresyonunun prognostik rolünün değerlendirilmesindeki güçlükler, kullanılan antikor heterojenitesi, çalışmamızda da olduğu gibi meme kanseri hasta gruplarının heterojen olmas1, hastaların evrelerinin heterojen olması, ald1kları tedavilerin heterojen olması, çalışma sonlanım noktalarının farklı olması, çalışma dizaynında planlanan sonucu göstermedeki gücün düşük olmas1 ve p53 ekspresyonu pozitifliği için kabul edilen eşik değerin farklı olması olarak düşünülmektedir.

Çalışmamızda p53 ekspresyonunun, kötü prognostik gösterge olan Kİ67 proliferasyon indeksi ve histolojik grad ile pozitif korele, ER ekspresyonu ile negatif korele olduğunun gösterilmesi ve Luminal A ve Luminal B-Her2 negatif grupta saptanan p53 boyanma yüzdesinin diğer alttiplere göre daha düşük oranda saptanmasının p53 ekspresyonunun meme kanserinde kötü prognoz ile ilişkili bir belirteç olabileceğini düşündürmektedir.

\section{Çıkar Çatıșması: Yok}

\section{REFERANSLAR}

1. Siegel RL, Miller KD, Jemal A. Cancer Statistics, 2017. CA Cancer J Clin. 2017;67(1):7-30.

2. Sorlie T, Perou C, Tibshirani T, ve ark. Gene expression patterns of breast carcinomas distinguish tumor subclasses with clinical implications. Proc Natl Acad Sci U S A. 2001;98(19):10869-74.

3. Vousden KH, Prives C. Blinded by the light: the growing complexity of p53. Cell 2009;137:413-31.

4. BiegingKT, Mello SS, Attardi LD. Unravellingmechanisms of p53-mediated tumour suppression. Nat. Rev. Cancer 2014;14:359-70.

5. Wade M, Li YC, Wahl GM. MDM2, MDMX and p53 in oncogenesis and cancer therapy. Nat.Rev. Cancer 2013;13:83-96.

6. Leroy B, Anderson M, Soussi T.. TP53 mutations in human cancer: database reassessment and prospects for the next decade. Hum. Mutat. 2014;35:672-88

7. The Clinical Lung Cancer Genome Project (CLCGP) and Network Genomic Medicine (NGM). A genomics-based classification of 
human lung tumors. Sci Transl Med 2013;5:209ra153.

doi:10.1126/scitranslmed.3006802.

8. Dumay A, Feugeas JP, Wittmer E, ve ark. Distinct tumor protein p53 mutants in breast cancer subgroups. Int $\mathbf{J}$ Cancer. 2013;132(5):1227-31.

9. Edge $\mathrm{SB}$, Byrd $\mathrm{DR}$, Compton $\mathrm{CC}$ ve ark. Breast. In: Edge SB, Byrd DR, Compton CC ve ark. AJCC Cancer Staging Manuel 7th ed. Springer Newyork Dordrecht Heidelberg London. 2010: 347-369

10. Goldhirsch A, Winer EP, Coates AS, ve ark. Personalizing the treatment of women with early breast cancer: highlights of the St Gallen International Expert Consensus on the Primary Therapy of Early Breast Cancer 2013.Ann Oncol. 2013;24(9):2206-23.

11. Blagosklonny MV. p53 from complexity to simplicity: mutant p53 stabilization, gain-offunction, and dominant-negative effect. FASEB journal. 2000;14:1901-7.

12. Murnyák B, Hortobágyi $T$. Immunohistochemical correlates of TP53 somatic mutations in cancer. Oncotarget. 2016;7(40):64910-20.

13. Lane DP. The regulation of $\mathrm{p} 53$ function: Steiner Award Lecture. Int $\mathrm{J}$ Cancer 1994;57:623-7.

14. Harris L, Fritsche $H$, Mennel $R$, ve ark. American Society of Clinical Oncology 2007 update of recommendations for the use of tumor markers in breast cancer. Journal of Clinical Oncology 2007;25:5287-312.

15. Allred DC, Clark GM, Elledge R, ve ark. Association of p53 protein expression with tumor cell proliferation rate and clinical outcome in node-negative breast cancer. $\mathrm{J}$ Natl Cancer Inst. 1993;85(3):200-6.
16. Gasparini G, Toi M, Verderio $P$, ve ark. Prognostic significance of p53, angiogenesis, and other conventional features in operable breast cancer: subanalysis in node-positive and node-negative patients. Int $\mathbf{J}$ Oncol. 1998;12(5):1117-25.

17. Lara JF, Thor AD, Dressler LG, ve ark. P53 Expression in node-positive breast cancer patients: results from the Cancer and Leukemia Group B 9344 Trial (159905). Clin Cancer Res. 2011;17(15): 5170-8.

18. Reed W, Hannisdal E, Boehler PJ, ve ark. The prognostic value of p53 and c-erb B-2 immunostaining is overrated for patients with lymph node negative breast carcinoma: a multivariate analysis of prognostic factors in 613 patients with a follow-up of 14-30 years. Cancer. 2000;88(4):804-13.

19. Yamamoto $M$, Hosoda $M$, Nakano $K$, ve ark. p53 accumulation is a strong predictor of recurrence in estrogen receptor-positive breast cancer patients treated with aromatase inhibitors. Cancer Sci. 2014;105(1):81-8.

20. Fountzilas G, Giannoulatou E, Alexopoulou Z, ve ark. TP53 mutations and protein immunopositivity may predict for poor outcome but also for trastuzumab benefit in patients with early breast cancer treated in the adjuvant setting.Oncotarget. 2016;7(22):3273153.

21. Kim JY, Park K, Jung HH, ve ark. Association between mutation and expression of TP53 as a potential prognostic marker of triple-negative breast vancer. Cancer Res Treat. 2016;48(4):1338-50. 